\title{
Podróż do Mezeritch. O doświadczeniu historii mówionej
}

Historię mówioną spośród innych metod badawczych historii wyróżnia obecność uczestnika/świadka minionych wydarzeń i jego opowieści o przeszłości. Podobnie jak obserwacja uczestnicząca, niejako zmusza praktykujących ją do spotkania z osobą, która widziała i pamięta, często również do doświadczenia inności spojrzenia na przeszłość. W swym modelu idealnym wymaga od historyka-badacza empatycznego wsłuchania się w opowieść, a więc odejścia od skupiania się na faktach oraz dyskursach, jakie przemawiają przez narratora, proponując w zamian koncentrację uwagi na nim samym i jego historii. Coraz częściej podnosi się również problem obecności badacza w powstawaniu historii opowiadanej; nie tylko w aspekcie jego na nią wpływu. Przykładem tego może być postulat Piotra Filipkowskiego, który zwraca uwagę na wymiar spotkania historyka z uczestnikiem/świadkiem minionych wydarzeń, zauważając, że historia mówiona „daje możliwość nie tylko na wgląd w ich samowiedzę, ale też w naszą [tj. badaczy, dop. A.S.] 
samowiedzę"1. Widoczne jest to również w coraz częstszym stosowaniu kategorii performansu w analizach historii mówionej ${ }^{2}$.

Wpływ sytuacji badawczej na historyka posługującego się historią mówioną lub/oraz jego późniejszą narrację, przywędrował do studiów nad przeszłością z antropologii i socjologii, gdzie jest dobrze znanym i opracowanym problemem. Wraz z rosnącą interdyscyplinarnością nauk o człowieku, wykorzystywaniem zbliżonych metod i narzędzi można by się spodziewać, że również praca historyka zostanie poddana tym samym pytaniom, zwłaszcza wobec rosnącej popularności historii mówionej wśród badaczy zajmujących się najmniej odległymi aspektami przeszłości. I choć metodologia nauk społecznych zajmuje ważne miejsce w rozważaniach nad historią najnowszą, to o doświadczeniu badawczym historyka, w kontekście historii mówionej, mówi się niewiele, a jeśli już, to zdecydowanie przeważa na tym polu refleksja teoretyczna, spychająca praktykę badawczą do ściśle specjalistycznych czasopism, jeśli nie do rozmów kuluarowych. O wadze tego problemu pisała Joanna Tokarska-Bakir w słynnym artykule Historia jako fetysz, w którym ostrzegała przed groźnymi konsekwencjami ukrywania wrażeń, jakie na historyka wywierają wydarzenia, o których pisze, w imię neutralności badawczej ${ }^{3}$.

W tekście poruszam problem doświadczenia historii mówionej oraz jego konsekwencji. Polem dla tej refleksji jest spotkanie historii mówionej z osiemdziesięciotrzyletnim wówczas panem Kazimierzem", dotyczące dziejów jednego z wielu polskich sztetl, którego zagłada dokonała się w czasie drugiej wojny światowej. Było ono częścią prowadzonego przeze mnie projektu historii mówionej, dotyczącego mojej rodzinnej miejscowości Międzyrzeca Podlaskiego. Początkowo nie miał on formalnych ram. Chciałam utrwalić pamięć o nieistniejącym żydowskim miasteczku, zanim i jej zabraknie. Rozmawiałam przede wszystkim z mieszkańcami okolicznych

Przytoczona wypowiedź została wygłoszona w czasie kolaboratorium „Dzielenie się pamięcią" zorganizowanego przez Fundację SPOT oraz Instytut Socjologii Uniwersytetu im. Adama Mickiewicza. Zapis wideospotkania dostępny na stronie: http://www. youtube.com/watch?v=kDzC1MCsTsg\&feature=relmfu (dostęp: 24. II 2014 r.).

2 Zob. np. W. Kudela-Świątek, Odpamiętane. O historii mówionej na przykładzie narracji kazachstańskich Polaków o represjach na tle narodowościowym i religijnym, Kraków 2013, s. 193-196.

3 J. Tokarska-Bakir, Historia jako fetysz, „Gazeta Wyborcza” z 14/15 II 2003 r.

4 Nazwisko narratora zgodnie z jego życzeniem zostało zastąpione inicjałem. 
wsi. Niektórych z nich znałam już wcześniej. Opisywane przedsięwzięcie okazało się dla mnie czymś więcej aniżeli "gromadzeniem relacji”. Stało się źródłem interesującego doświadczenia związanego z praktyką badawczą. Kończąc uwagi wstępne, słów kilka należy poświęcić kompozycji tekstu. Fragmenty wywiadu przeplatają się w nim z opisem historycznym i analizą metodologii badawczej. Ten pozorny chaos ma na celu oddanie struktury doświadczenia badawczego, które, początkowo nieuporządkowane, pod wpływem pracy nad usłyszanym tekstem, stopniowo zyskuje tożsamość, podobnie jak „ja” autora.

\section{Mezeritch}

W ramach pracy nad doktoratem gromadziłam historie opowiadane, w tym dotyczące m.in. relacji polsko-żydowskich. Swoje badania, jak wspominałam wyżej, prowadziłam w miejscowości, w której się urodziłam, w której chodziłam do szkoły. Temat historii Żydów, niegdyś zamieszkujących to miasto, do początku pierwszego dziesięciolecia XXI w. właściwie tu nie istniał. Także z tej perspektywy historia Międzyrzeca jest podobna do dziejów wielu innych polskich miast na wschodzie Polski. Przed wojną zamieszkiwała je ważna dla kultury i historii miasta wspólnota żydowska, licząca wówczas około dwunastu tysięcy osób. Żydzi stanowili siedemdziesiąt pięć procent ogółu ludności ${ }^{6}$. Dziś, z ponad siedemnastu tysięcy mieszkańców miasta ${ }^{7}$, niewielu o nich pamięta. O ich niegdysiejszej obecności nie świadczy niestety wspaniała synagoga, która została zburzona w czasie wojny, lecz cmentarz oraz tablica i pomnik upamiętniające zagładę międzyrzeckich Żydów, a także wspomnienia najstarszego pokolenia mieszkańców miasta i jego okolic, które chciałam zarejestrować.

5 Użyty w tym miejscu cudzysłów wskazuje na określone podejście zarówno do metody historii mówionej, jak i samych źródeł. Zgodnie z mechanizmami działania pamięci, jej związków z wyobraźnią, historie opowiadane nie są „relacjonowaniem” przeszłości, lecz oralną artykulacją - opowiadaniem - doświadczenia biograficznego wraz ze wszystkimi konsekwencjami tego faktu. Zob.: M. Kurkowska-Budzan, Antykomunistyczne podziemie zbrojne. Analiza współczesnej symbolicznej przeszłości, Kraków 2009, s. 32.

6 Dane za http://www.sztetl.org.pl/pl/article/miedzyrzec-podlaski/3,historia-miejscowosci/ (dostęp: 24 II 2014 r.).

$7 \quad$ L. Nowak, J. Stańczyk, A. Znajewska, Ludność. Stan i struktura $w$ przekroju terytorialnym (stan w dniu 31 XII 2007), Warszawa 2008. 
Moja pozycja, jako prowadzącej badania, była ambiwalentna. $\mathrm{Z}$ jednej strony, opowiadający, w tym pan Kazimierz, znali mnie jako córkę i wnuczkę określonych osób, zapewne pamiętali mnie też jako małą dziewczynkę. Z drugiej, wiedzieli, że skończyłam studia historyczne, tłumaczyłam im też cel swoich poszukiwań pamięci o Międzyrzecu. Dzięki temu, że byłam miejscowa łatwiej było mi dotrzeć do moich późniejszych rozmówców. Ponadto, jako że historia mówiona jest zarówno sytuacją dzielenia się pamięcią i tożsamością, często przed rozmową przeprowadzający wywiady muszą udowodnić, że są godni zaufania, że można powierzyć im ciężar wspomnień, co odnosi się zwłaszcza do trudnych relacji polsko-żydowskich $^{8}$. Mnie ten problem z oczywistych powodów ominął. Pan Kazimierz, podobnie jak inne osoby, z którymi rozmawiałam, przyjął mnie jako swoją i opowiedział mi m.in., jak pamięta drugą wojnę światową oraz żydowski Mezeritch i jego zagładę. Niewykluczone, że również dlatego, iż nie był on bezpośrednio uwikłany w wydarzenia, o których opowiadał. Był jedynie ich obserwatorem. Prawdopodobnie nie zdawał sobie sprawy z dyskusji na temat odpowiedzialności za zagładę osób przyjmujących bierną postawę w jej obliczu. Nie mogę jednak wykluczyć, że z faktu, iż byłam miejscowa, nie mówił o sytuacjach, które przedstawiałyby go w tzw. złym świetle, znajdujących się poza moją wiedzą.

Po kilku rozmowach miałam coraz większą świadomość pamięci miejsca. Opowiadano mi o przedwojennym Międzyrzecu, o lokalnych wydarzeniach w czasie drugiej wojny światowej: o tym jak jej wybuch zastał kogoś na łące, w trakcie sianokosów, jak chowano się w specjalnie przygotowanej kryjówce, między drewnem składowanym na opał. Mówiono także o Żydach, o ich sklepach, o synagodze, a także o getcie i jego likwidacji. Dzielono się ze mną również strachem i poczuciem bezradności, jakie towarzyszyło byciu biernym świadkiem zagłady Żydów. Pod tym kątem szczególne było właśnie spotkanie z panem Kazimierzem. Była to też pierwsza z rozmów, którą przeprowadziłam w ramach już sformalizowanego projektu'. Gdy wybuchła druga wojna światowa miał 12 lat, właściwie wokół tego wydarzenia koncentrowała się

8 Obszerniej na ten temat zob.: M. Kurkowska-Budzan, Badacz-tubylec. O emocjach, władzy i tożsamości w badaniach oral history miasteczka Jedwabne, [w:] Obserwacja uczestniczaca w naukach historycznych, red. B. Wagner, T. Wiślicz, Zabrze 2008.

$9 \quad$ Jeszcze w czasie studiów magisterskich uczestniczyłam w warsztatach historii mówionej, prowadzonych przez lubelski Ośrodek Brama Grodzka Teatr NN. Posiadałam już wówczas doświadczenie w przeprowadzaniu rozmów historii mówionej. 
jego opowieść. Powstała ona w modelu historii mówionej, którą Alessan-

dro Portelli określił jako thick dialogue; pan Kazimierz opowiadał swoją historię, odpowiadając na moje pytania. Po części było to spowodowane tym, że często urywał swoją wypowiedź, popadając w zamyślenie. Mówił jednak chętnie, żadne ze stawianych przeze mnie pytań nie spowodowało jego zakłopotania. Często podkreślał, że chciałby dodać coś jeszcze, ale już nie pamięta. Wspomniał też, że interesował się lokalną historią. W czasie naszego spotkania, opowiedział mi, że:

„[p]rzed wojną to było po prostu miasto żydowskie; mieszkało w nim parę tysięcy Żydów. Prawie wszystkie sklepy mieli Żydzi w swoich rękach, tylko jeden Stanisław Prokopiak miał polski sklep. Rozmaite sklepy były; był żelazny na przykład. Pamiętam go dobrze, ponieważ mój stryj był kowalem i gdy ktoś robił u niego wóz i nie wiedział, jakie części ma kupić, jeździli tam razem z nim. Były też i inne sklepy, a najwięcej było rzemieślników, szewców i krawców, stolarzy i kowali. Jarmarki się odbywały; konie, świnie i krowy, cielęta, rozmaicie to było. Żydzi handlowali, przyjeżdżali przez wsie. Taki był Jankiel, ale jak on na nazwisko miał, to nie pamiętam, za cielętami jeździł, kupywał cielaki na mięso, bo przecież Żydzi świńskiego mięsa nie jedli, tylko kurze, kacze, gęsi, takie, baranie i cielaki. Pamiętam, że przed wojną to było brudne miasto, bo Żydzi nie dbali o to wszystko. Prawie wszystkie domy były drewniane, rzadko gdzie był dom murowany jak teraz. Nie było za słodko, bo ludzie nie mieli pracy i chodzili na zarobek do gospodarzy"10.

W historii opowiadanej pana Kazimierza Żydzi występują w sposób naturalny, czego nie zmienia fakt, że powodowane to było również moimi pytaniami - tak jak wspominałam - rozmowa jako taka przybrała formę pytań i mniej lub bardziej rozbudowanych odpowiedzi na nie. W opowieści mojego rozmówcy stykają się dwie rzeczywistości: wiejska i miejska. Pan Kazimierz uczył się i pracował w Międzyrzecu, przygotowywał się do wykonywania zawodu stolarza, mieszkał jednak w okolicznej wsi. Mówił o tym, co było mu bliskie, co znał z własnego doświadczenia. Jego obraz przedwojennego i wojennego miasta pokrywa się z ustaleniami historyków.

10 Historia opowiadana Kazimierza J. 23 VII 2010 r. (świadectwo sporządziła A. Stolarz; oprac. A. Stolarz), Archiwum Ośrodka Brama Grodzka, J. K. (1927); archiwum autorki. 
Wybrał dla niego inną - narracyjną - formę. Informację o tym, że w latach dwudziestych XX w. ludność żydowska stanowiła prawie siedemdziesiąt pięć procent ogółu mieszkańców, która modliła się w dziesięciu domach modlitwy, w razie potrzeby leczyła w żydowskim szpitalu, a dzieci uczyły się w czterdziestu pięciu cheredarch ${ }^{11}$, opowiadający przekazuje poprzez opis żydowskich sklepów, w których robił zakupy. Z kolei bardziej szczegółowy wątek spotkania, mianowicie temat relacji polsko-żydowskich w miasteczku, poruszył już na moją prośbę.

„Relacje z Żydami były przyjazne, ale już przed samą wojną to już tak nie było. Było hasło: »Bij Żyda!« Taka była nienawiść po prostu. Uczniowie Polacy na Żydów jak się raz zebrali, to Żydzi uciekali ulicami, a oni za nimi rzucali kamieniami. Ci Żydzi, którzy mieli chałupę przy szosie, to okiennice zamykali, żeby szyb im nie powybijali. Taki chłopak z czwartej klasy, czy z piątej, już nie pamiętam, jak jednego żydowskiego ucznia uderzył kamieniem w głowę, to on upadł i zalał się krwią. Temu chłopcu nauczyciele nic nie zrobili, bo to wtedy było takie hasło: »Bij Żyda!« Później Żydzi już mieli strach i wyjeżdżali jak już wojna nachodziła, chowali się po wsiach, gdzie tylko który mógł i to duże pieniądze za to dawali. Taka to robota z tymi Żydami, oni prześladowani byli..." ${ }^{12}$.

W swojej opowieści narrator ujawnia ambiwalentny stosunek do ludności żydowskiej. Z jednej strony, w jego wypowiedzi pojawiają się pojedyncze negatywne opinie („Żydzi nie dbali o to wszystko”). Dokonuje podziału na Polaków i Żydów. Nie wyraża też jednoznacznej dezaprobaty postępowania „polskich uczniów”. Z drugiej strony, często mówi o „nienawiści”, „braku miłosierdzia”, o tym, że Żydzi byli „prześladowani”, podkreśla ich ciężki los w czasie wojny oraz jego niesprawiedliwość. Uwidacznia się to m.in. w opisie getta, które przedstawia jako duszne „osiedle” - „jakby ich ktoś pozamykał w jakiejś kajucie i się tam dusili bardzo”. Jednocześnie, bez wyraźnej

11 Zob.: M. Kubiszyn, Historia: Międzyrzec Podlaski http://www.sztetl.org.pl/pl/article/miedzyrzec-podlaski/5,historia/ (dostęp: 24 II 2014 r.); A. Trzciński, Śladami zabytków kultury żydowskiej na Lubelszczyźnie, Lublin 1990; Międzyrzec Podlaski, [w:] Pamiątki i zabytki kultury żydowskiej w Polsce, oprac. P. Burchard, Warszawa 1990; A. Trzciński, J. Sobota, Cmentarze żydowskie w Międzyrzecu Podlaskim, Lublin 2009.

12 Historia opowiadana Kazimierza J., op. cit. 
oceny, wspomina o ludziach, którzy wykorzystywali ówczesną sytuację dla własnych korzyści (np. dostarczali za pieniądze jedzenie do getta). Fragment swojej wypowiedzi na ten temat kończy stwierdzeniem: „niektórzy się pobogacili, a niektórzy to stracili życie...”. Po czym zapada w milczenie. Czynił to często w trudnych dla niego momentach spotkania. Dopowiadał także, że chciałby coś jeszcze dodać, ale już nie pamięta. W podobny sposób opowiadał również o likwidacji getta.

„Gdy pracowałem w terminie, to mnie majster wysłał ze swoją córeczką do sióstr zakonnych, które mieszkały w takim drewnianym domu, tu zaraz za pałacem Potockich, bo ta córeczka tam często chodziła, a ja nie wiedziałem gdzie to jest. Robiliśmy dla nich ramy do obrazu Ostatniej Wieczerzy. Siostry poczęstowały nas herbatą. Gdy wyszliśmy na drogę, zobaczyłem, że drogą jedzie cały samochód Niemców i karabin maszynowy nad szoferką do strzału gotowy. Żydów gnali z miasta, stamtąd gdzie ten pomnik z orłem stoi [tj. obecnie plac Jana Pawła II, dop. A.S.]. Gnali ich w tę stronę, tutaj gdzie teraz jest jajczarnia, bo przedtem tej jajczarni nie było, tylko inne budynki tam dalej stały, chyba przed wojną była ubojnia zwierząt, ale jak Niemcy przyszli to postawili sobie baraki drewniane. Obok tych Żydów z jednej strony i z drugiej strony szli Niemcy z karabinami, i tylko jak któryś Żyd gdzieś uciekał, to by zaraz rozstrzelali, któryś nie da rady iść, to strzelali i zostawiali na drodze, później furmanki jechały i zbierali te ciała i ich wywozili na kirkut za Międzyrzec. [...] Potem wprowadzili Żydów do tych baraków, tam już wtedy tych Niemców nie było, bo pojechali na front, były baraki puste. I w nocy przyjechał pociąg koło żelaznego mostu. Tam stał pociąg i tych Żydów z tych baraków w ten pociąg i wywieźli ich chyba do Treblinki... I [...] później gdzie jakiś, jakiś tylko się Żyd ukazał, a taki był Niemiec Szlejga Franc, Franek Szlejga, on Żydów nie lubiał, aby tylko gdzieś... miłosierdzia nad ludźmi nad tymi Żydami [nie miał]”13.

13 Historia opowiadana Kazimierza J., op. cit. Wydarzenia, o których tu mowa, miały miejsce 25 i 26 sierpnia $1942 \mathrm{r}$. Opowiadający miał wtedy 15 lat. Niemcy najpierw zgromadzili wszystkich Żydów na rynku; rozstrzelali około tysiąca chorych i niedołężnych, a pozostałe jedenaście tysięcy wywieźli do obozu zagłady. Na ich miejsce, do Międzyrzeca, przesiedlono Żydów z Radzynia Podlaskiego i jego okolic, którzy wkrótce podzielili ich los. Ostateczna likwidacja getta w Międzyrzecu rozpoczęła się w maju 1943 r., przestało ono istnieć 17 lipca 1943 r. Także w tym przypadku, opowieść mojego rozmówcy w dużej części pokrywa się z ustaleniami historyków na temat tego wydarzenia, zob. np. M. Kubiszyn, op. cit; ; A. Trzciński, J. Sobota, op. cit. 
Jak wiadomo, historia mówiona to nie tylko wypowiedziany tekst, konkretne słowa, daty i nazwiska, to również cała strefa pozawerbalnych znaków, cisza, zamyślenia, niespodziewana zmiana tematu. Często ich śladu nie ma nawet na najlepiej sporządzonej transkrypcji, dlatego też podkreśla się wagę samodzielnego przeprowadzania wywiadów przez badaczy, oczywiście jeżeli istnieją ku temu możliwości. Zdarza się, że to właśnie w pozasłownych sygnałach zawarta jest część interpretacji wydarzeń. W tym kontekście należy odnotować, że narracji towarzyszyło swego rodzaju poczucie bezsilności wobec wydarzeń, których świadkiem był opowiadający. Wynika to nie tylko z jego słów - zapytany raz jeszcze, już po zakończeniu nagrania, o to, czy słyszał, by ktoś w okolicy pomagał Żydom, ukrywał ich, odpowiedział: ,ja się bałem, ludzie się bali po prostu, przecież ja ich znałem, ludzie ich znali, ale jak to strach był patrzeć na to, co się działo"14. Echo tego strachu słyszałam w jego opowieści, głosie oraz ciszy, która pojawiała się między poszczególnymi fragmentami opowieści o wojnie i zagładzie nieistniejącego już sztetl.

Choć być może zabrzmi to banalnie, dzięki opowieści pana Kazimierza uświadomiłam sobie, że relacji polsko-żydowskich w czasie drugiej wojny światowej nie da się przedstawić w czarno-białych barwach, z prostym podziałem na tych, którzy pomagali Żydom, i na tych, którzy przyjmowali postawę bierną, gdy mogli pomóc, z ich jednoznaczną negatywną oceną. Pomiędzy pomaganiem Żydom, a bogaceniem się na ich tragedii, istniał także obezwładniający strach, niepozwalający na nic więcej niż tylko „obserwowanie”. Przykładem tego, w mojej opinii, jest właśnie zachowanie pana Kazimierza. Nie chodzi mi tu o usprawiedliwianie takich postaw ani też o ich generalizowanie, lecz o próbę ich zrozumienia. Doświadczenie to wpłynęło na mój sposób myślenia o zagładzie. Dzięki niemu oparło się ono zarówno na świadectwach ofiar i teoretycznych rozważaniach, pisanych z poznawczego dystansu, oraz na opowieści osoby, będącej jej biernym świadkiem, który - parafrazując Zygmunta Baumana - patrzył ze zgrozą, ale nic, w swojej opinii, nie mógł zrobić.

Opisane wyżej spotkanie historii mówionej było dla mnie jednocześnie swego rodzaju podróżą w czas miniony, gdy Międzyrzec nazywano również Mezeritch z jego gwarnym rynkiem, otoczonym kamieniczkami z żydowskimi sklepami i z jego synagogą, której nigdy nie mogłam

14 Historia opowiadana Kazimierza J., op. cit. 
zobaczyć $^{15}$. Doświadczenie to uświadomiło mi, jak wielki dysonans istnieje pomiędzy pamięcią indywidualną a społeczną, zwłaszcza w kontekście relacji polsko-żydowskich. O Żydach w Międzyrzecu właściwie się nie mówiło, nie istnieli też w dyskursie społecznym aż do czasu odsłonięcia pomnika upamiętniającego ofiary zagłady w maju 2009 r., którego istnienia, mimo że został ustawiony na głównym placu miasta, świadoma jest stosunkowo niewielka liczba mieszkańców miasta i okolic ${ }^{16}$. Jednakże pamięć o nich jest wciąż żywa w najstarszym pokoleniu, co pokazuje przykład pana Kazimierza. Żydzi pojawili się w opowieści o miasteczku w sposób oczywisty, jako nieodłączny element minionego krajobrazu lokalnej społeczności; wyłaniali się ze wspomnień targów i jarmarków, z opisu nieistniejącej już lub w dużej mierze zmienionej przestrzeni miejskiej (synagoga), wreszcie szkoły (opisy dyskryminacji uczniów pochodzenia żydowskiego) ${ }^{17}$.

Historia mówiona jako doświadczenie historyczne i „wymiana” Wrażenia, które towarzyszyły mi podczas opisanego spotkania, można by, idąc szlakiem wytyczonym przez Jamesa Clifforda dla antropologii, określić jako rodzaj „intuicji”. Badacz podkreślał mglistość doświadczenia etnograficznego, co nie oznacza jego negacji; stwierdził, że jest to coś, „co ktoś ma lub nie i powoływanie się na nie ma często posmak mistyfikacji”, jednocześnie zauważając, iż może być to rodzaj strategii budowania autorytetu w tekście, zwłaszcza w przypadku tak charyzmatycznych badaczy jak niegdyś

15 Zdjęcia makiety synagogi dostępne są na stronie http://www.sztetl.org.pl/pl/article/ miedzyrzec-podlaski/11,synagogi-domy-modlitwy-i-inne/430,nowa-synagoga-wmiedzyrzecu-podlaskim-nieistniejaca-/ (dostęp: 24 II 2014 r.).

16 Przekonałam się o tym podczas jednego ze spotkań, gdy moja rozmówczyni w trakcie swojej opowieści wspomniała, że „zdaje się, że gdzieś na skwerku jest pomnik Żydów, biskup go przyjeżdżał święcić”.

17 Z badań nad narracyjną artykulacją przeszłości wiemy, że we wspomnieniach i nie tylko, opowiada się o tym, co obejmuje horyzont mówiącego, zaś milczeniem pokrywa się to, co jest dla niego oczywiste oraz co za niego wykracza. Zob. np.: Narracja jako sposób rozumienia świata, red. J. Trzebiński, Gdańsk 2002; K.M. Langellier, R.E. Petereson, Storytelling in Daily Life: Performing Narrative, Philadelphia 2004; M. Głowiński: Document as Novel, „New Literary History”, vol. 18, no. 2; Literacy, Popular Culture, and the Writing of History (zima, 1987), s. 385-401, polskie wydanie tekstu: Dokument jako powieść, [w:] M. Głowiński, Narracje literackie i nieliterackie. Prace wybrane, t. II, Kraków 1997, s. 123-142. 
Bronisław Malinowski i Margaret Mead ${ }^{18}$. Chcąc zatem spojrzeć na doświadczenie badawcze z epistemologicznej perspektywy, można zatem potraktować je jako „weryfikację”, ewentualnie „podstawę” wiedzy. Odwołując się do własnej eksperiencji, muszę przyznać, iż nie jest novum stwierdzenie dysproporcji pomiędzy pamięcią społeczną a indywidualną, zwłaszcza na przykładzie polskich lokalnych społeczności. Zagadnienie to jest dobrze opisane w literaturze. Zapewne w trakcie dalszych badań przekonałabym się o tym niejednokrotnie. Podobnie rzecz się ma zarówno z problemem relacji polsko-żydowskich w przedwojennej Polsce, jak i pomocy Żydom w czasie wojny.

Opisana sytuacja historii mówionej była dla mnie przede wszystkim swego rodzaju przeżyciem. W takim kontekście o doświadczeniu historycznym pisze Franklin R. Ankersmit, powołujący się na ustalenia Johana Huizingi. Według autora Sublime Historical Experience, ,jest to coś,

18 J. Clifford, O autorytecie etnograficznym, tłum. J. Iracka, S. Sikora, [w:] Amerykańska antropologia postmodernistyczna, wybór i red. M. Buchowski, Warszawa 1999, s. 138. Antropolog dochodzi do wniosku, że „doświadczenie etnograficzne można rozumieć jako budowanie wspólnego, znaczącego świata, czerpanie z odczuwania bliskiego intuicji, postrzeganiu i przypuszczaniu. W ten sposób wykorzystuje się wskazówki, ślady, gesty i strzępki sensów zanim dopracuje się mocnej interpretacji. Takie fragmentaryczne doświadczenia można zaklasyfikować jako estetyczne i/lub związane z przeczuciami", zob. ibidem, s. 139. Jako przykład, Clifford podaje twórczość Margaret Mead, zaś by potwierdzić swoją tezę na temat roli doświadczenia etnograficznego u Mead przywołuje recenzję jej książki Dorastanie na Nowej Gwinei, Alfreda Louisa Kroebera. Jej autor w następujący sposób podsumowuje tę publikację: „Przede wszystkim jasno widać, że Margaret Mead ma w niezwykłym stopniu zdolność szybkiego dostrzegania najważniejszych nurtów oddziałujących na jednostkę w danej kulturze i nakreślenia ich w zwięzłych szkicach o zadziwiającej ostrości, których rezultatem jest przedstawienie o niezwykłej żywności i pozorze życia. Oczywiście, u podłoża tej zdolności leży dar zintelektualizowanej, lecz silnej sensualności, jak również wysokiej klasy intuicji, rozumianej jako umiejętność stworzenia całościowego przekonywującego obrazu na podstawie wskazówek, ponieważ tylko tym mogły być niektóre z jej danych, jeśli weźmiemy pod uwagę, że miała zaledwie sześć miesięcy na naukę języka i wejście do wnętrza kultury jako całości, koncentrując się ponadto na obserwowaniu zachowania dzieci. W każdym razie, gdy chodzi o obraz, jest on całkowicie przekonujący dla recenzenta, który nie skrywa podziwu dla pewności wglądu i biegłości pociągnięć pióra, z których powstaje opis”. Zob. A.L. Kroeber, rec. z M. Mead, Growing up in New Guinea, „American Anthropologist" 1931, vol. 36, no. 249, s. 248, cyt. za J. Clifford, O autorytecie etnograficznym, op. cit. 
co historyk bardziej przeżywa, aniżeli jest w stanie świadomie wywołać czy powtórzyć [...], jest oszołomieniem chwili. W doświadczeniu historycznym historyk ma wrażenie bycia w bezpośrednim i absolutnie autentycznym kontakcie z przeszłością"19. Zdaniem obydwu badaczy wywołać je mogą przedmioty, jak np. stary rękopis, ale i wejście do budynku, niezmienianego od lat, a u Ankersmita także nostalgiczne wspomnienie ${ }^{20}$. Stwierdza on, że doświadczenie historyczne ma w sobie coś z objawienia, a to z kolei posiada znamiona autentyczności. Jego zdaniem doświadczenie przeszłości nie może być iluzją, jest tak samo rzeczywiste i wiarygodne jak to, co jest nam dane $\mathrm{w}$ bezpośrednim doznaniu zmysłowym ${ }^{21}$. Dlatego też holenderski badacz porównuje doświadczenie historyczne do estetycznego: „jest poznaniem, które prowadzi nas do mieszczącej się w rzeczywistości prawdy"22, stwierdza filozof historii. Ewa Domańska, analizująca pisarstwo Ankersmita, zauważa, że w jego teorii „doświadczenie historyczne ma zatem charakter antykognitywny, a więc nie dostarcza wiedzy o przeszłości, ale może skłonić, by patrzeć na nią w określony sposób [...] jest bowiem doświadczeniem, które nas zmienia" ${ }^{23}$ (w przeciwieństwie do Huizingi, u którego można odnaleźć elementy jego epistemologicznego ujęcia ${ }^{24}$ ).

19 F.R. Ankersmit, Modernistyczna prawda, postmodernistyczne przedstawienie i po-postmodernistyczne doświadczenie, [w:] Historia o jeden świat za daleko? wstęp, przekł. i oprac. E. Domańska, Poznań 1997, s. 27.

20 Idem, Historiografia i postmodernizm, przeł. E. Domańska, [w:] Postmodernizm. Antologia przekładów, wybór, oprac. i wstęp R. Nycz, Kraków 1998.

21 Idem, Narracja, reprezentacja, doświadczenia. Studia z teorii historiografii, red. E. Domańska, Kraków 2004, s. 223.

22 Idem, Język a doświadczenie historyczne, przeł. S. Sikora, „Konteksty: polska sztuka ludowa: antropologia kultury, etnografia, sztuka" 1997, nr 1-2, t. 51, s. 83.

23 E. Domańska, Historia egzystencjalna, Warszawa 2013, s. 57.

24 Ankersmit zasadniczo wywodzi swoje rozumienie doświadczenia historycznego od Huizingi. Sam Johan Huizinga, który tylko w kilku akapitach pisze o doświadczeniu historycznym, używa określenia „historical sensation”, a więc doznanie historyczne. Rozumie je w następujący sposób: „W każdej historycznej świadomości istnieje doniosły komponent, najstosowniej charakteryzowany w kategorii doznania historycznego. Można również mówić o kontakcie historycznym. Wyrażenie wyobraźnia historyczna mówi zbyt wiele i to samo dotyczy wizji historycznej, o ile pokrewne pojęcie przedstawienia wizualnego sugeruje stopień determinacji, który jest tu wciąż nieobecny. Niemieckie słowo „Ahnung”, którego Wilhelm von Humboldt użył w związku z tym, prawie by to wyraziło, gdyby termin ten nie stracił dokładnego znaczenia przez to, że bywał używany w innym kontekście. [...] Jeżeli jest 

smita, które - by przytoczyć raz jeszcze słowa Ewy Domańskiej - nie dostarcza „wiedzy o przeszłości, ale może skłonić, by patrzeć na nią w określony sposób”, posiadazatem wymiar egzystencjalny. Jak zauważa Dorota Wolska, nawet „największe umysły dość zgodnie uznają doświadczenie za wyjątkowo oporne wobec systematycznych wyjaśnień, jeśli nie »beznadziejne« w tym względzie”25. Ankersmitowskie „znamiona autentyczności” i poczucie „rzeczywistego

to naprawdę element rozumienia historii, które często bywa określane terminem „Nacherleben”, to termin ten jest zupełnie źle rozumiany. „Nacherleben” za bardzo wskazuje na proces psychiczny. Doznanie historyczne nie przedstawia się nam jako ponowne przeżycie, ale jako rozumienie podobne do rozumienia muzyki, albo raczej świata muzyki”. Zob.: J. Huizinga, De taak der cultuurgeschiedenis [w:] Huizinga, Verzamelde Warken 7: Geschiedwetenschap, Hedendaagsche Cultuur, Harlem 1950, S. 71-72, cytat za: F. Ankersmit, Sublime Historical Experience, Stanford University Press 2005, s. 120-121 (przekład na j. ang. F. Ankersmit, przekład polski za E. Fiksa). Huizinga pisze również „Ów niedający się całkowicie zredukować kontakt z przeszłością, polegający jakby na wejściu w pewną atmosferę, stanowi jedną z wielu dostępnych człowiekowi form wychodzenia poza samego siebie, doświadczania prawdy. Nie jest to ani zadowolenie estetyczne, ani przeżycie religijne, ani wzniosły podziw odczuwany wobec przyrody ani metafizyczne rozpoznawanie czegoś - choć jednak jest to coś z rzędu odczuć podobnych. Przedmiotem takiego doznania nie są ludzkie myśli, które ma się nadzieję rozwikłać. To, co umysł stwarza, czego doświadcza w takim związku, trudno nazwać obrazem. Jeśli doznanie to przybiera w ogóle jakąś formę i jakąkolwiek by formę przybrało, pozostaje zawsze skomplikowane i bliżej nieokreślone: jakaś »Ahnung«, jakieś »przeczucie«, zarówno dróg, domów i pól, dźwięków i barw, jak i działających i oddziaływających na nas ludzi. Ten kontakt z przeszłością, któremu towarzyszy całkowite przeświadczenie o autentyczności i prawdzie, może być wywołany przez jeden wiersz jakiegoś dokumentu, rejestru wydarzeń, jakiś druk, przez kilka nut pieśni. Nie wnosi go do swej pracy sam piszący, używając pewnych słów. Ów czynnik znajduje się gdzieś poza książką o historii, nie w niej. To czytelnik dostarcza go piszącemu jako własna odpowiedź na jego wyzwanie. [...] W rzeczywistości doznanie to, wizja, kontakt. „Ahnung” ogranicza się do momentów szczególnej, jasnej przenikliwości intelektualnej, momentów nagłej penetracji ducha". Zob. J. Huizinga, The Task of Cultural History, [w:] Men and Ideas, History, The Middle Ages, the Renaissance. Essays, tłum. J.S. Holmes, H. van Marle, New York 1990, s. 52-54, polskie tłum. cytatu za W. Juszczak, Wędrówka do źródet, słowo/obraz terytoria, Gdańsk 2009, s. 38.

25 Por.: D. Wolska, Odzyskać doświadczenie. Sporny temat humanistyki wspótczesnej, Kraków 2012, s. 8-9. 
kontaktu z przeszłością", a więc doświadczenie atmosfery dawnego Mezeritch, którego doznałam w czasie spotkania, wprowadzają zatem w egzystencjalny zakres doświadczenia historii mówionej, nadając jej tym samym kolejny wymiar: jako formy przeżywania rzeczywistości minionej, bycia w niej, co z kolei może wpłynąć na sposób jej postrzegania ${ }^{26}$. Dostrzegam to we własnej praktyce badawczej. Doświadczenie historii mówionej było nie tylko „podróżą do odległego kraju", ale wpłynęło także na mój sposób myślenia o zagładzie. Przełożyło się też na sposób prowadzenia rozmów historii mówionej, w zadawanych pytaniach oraz w przyjmowanej postawie badawczej, która stała się bardziej empatyczna i ukierunkowana przede wszystkim na słuchanie i rozumienie w miejsce oceny. Podobnie jak w przypadku innych badaczy, z doświadczenia wyprowadziłam teoretyczny model historii mówionej, choć oczywiście już wcześniej posiadałam określone przygotowanie do przeprowadzania wywiadów. Znalazł on zastosowanie w późniejszych projektach ${ }^{27}$.

W związku z powyższym historię mówioną można postrzegać jako sytuację „wymiany”. Uzasadnia to również przywoływana na wstępie kategoria performansu, stosowana $w$ refleksji nad tą metodą gromadzenia informacji. Pokazuje ona, że nie tylko badacz wpływa na opowiadającego i jego opowieść, lecz także opowiadający na badacza, w konsekwencji zaś może oddziaływać również na jego narrację. Problem ten rozwija Anna Wyka, socjolożka prowadząca rozważania nad metodologią badań jakościowych, która stwierdza, że charakterystyczne dla niej podmiotowe podejście, może zaowocować określonym rodzajem sytuacji badania, mianowicie „wymianą". Wynika to z jej założeń o budowaniu kontaktu badawczego na wzór zwykłej relacji międzyludzkiej opartej na wzajemności, tudzież na jednoczesnym porzuceniu hermeneutyki podejrzliwości, która zostaje zastąpiona wzajemnym szacunkiem, zaufaniem. Jest to umowa, dzięki której, jak pisze socjolożka, „badanie staje się »wspólną drogą«, w której badani »znają swoje życie«, »znają teren«,

26 Ibidem.

27 F. Maubach, Świadek historii. Swobodne wspominanie a krytyka źródta historycznego - o ambiwalencji metody w zachodnioniemieckiej oral history okoto roku 1980 , „Wrocławski Rocznik Historii Mówionej” 2013, R. III, s. 46. W ramach prac nad rozprawą doktorską gromadziłam także historie opowiadane dotyczące historii Katolickiego Uniwersytetu Lubelskiego w okresie PRL. W tym przypadku rozmawiałam przede wszystkim z emerytowanymi pracownikami naukowymi uniwersytetu. 
a badacze »mają przewodnik«, przy czym żadne z narzędzi nie jest sztywne i może być modyfikowane w trakcie procesu badawczego" 28 .

Jeśli spojrzymy na metodę historii mówionej jako na sytuację „wymiany", dzielenia się pamięcią i tożsamością, możemy potraktować ją, idąc śladem Michela Foucaulta i antropolożki genderowej Hellen Callawey, jako sytuację pozwalającą dowiedzieć się, w jaki sposób definiujemy swoją tożsamość, a następnie jak wpływa to na gromadzenie danych o badanym wycinku minionej rzeczywistości, w kolejności na powstający tekst ${ }^{29}$. Opowieści o przeszłości powstają dzięki medium dialogu, ze wszystkimi wynikającymi z tego konsekwencjami. Później zaś ten wielopoziomowy dyskurs zostaje transmutowany w tekst ${ }^{30}$.

Rozważając własne doświadczenie historii mówionej w szerszej perspektywie, mogę stwierdzić, iż odcisnęło się ono także na moim podejściu do

28 A. Wyka, Badacz społeczny wobec doświadczenia, Warszawa 1993, s. 20-25; por. A. Giza, Życie jako opowieść: analiza materiałów autobiograficznych w perspektywie socjologii wiedzy, Wrocław 1991; K. Lutyńska, Wprowadzenie do panelu. Co zniknęło, co zostało, co jest nowe $w$ badaniach empirycznych prowadzonych $w$ Polsce $w$ latach dziewięćdziesiątych, „Kultura i Społeczeństwo” 1993, nr 3; eadem, Surveye w Polsce. Spojrzenie socjologiczno-antropologiczne. Wybrane zagadnienia, Warszawa 1993.

Hellen Callaway prowadzi interesujące rozważania na temat doświadczenia etnograficznego w przypadku badań genderowych. Zob. Ethnography and experience. Gender implications in fieldwork and texts, [w:] Anthropology and autobiography, red. J. Okely, London-New York 1995, s. 29-46.

Por. ibidem, s. 3o. Potwierdzenie takiej teorii odnaleźć można ponownie u Jamesa Clifforda, analizującego przykład doświadczenia etnograficznego u Maurice'a Leenhardta, którego słowa zyskują na znaczeniu w kontekście jego praktyki badawczej: niezwykle długiego pobytu w terenie oraz doskonałej znajomości języka, a więc dwóch z podstawowych wymagań warsztatowych jego profesji. Leenhardt, na podstawie prowadzonych badań, konkluduje: „w rzeczywistości kontaktu z innym nie osiągniemy przez analizę. Raczej rozumiemy go w jego całości. Z początku możemy naszkicować jego obraz za pomocą zarysu lub symbolicznego szczegółu, który zawiera w sobie całość i przywołuje jego naturę w prawdziwej formie. Ta ostatnia umyka nam, jeśli podchodzimy do naszego bliźniego, posługując się jedynie kategoriami intelektualnymi”. M. Leenhardt, Do Kamo: Person and Myth in the Melansian World, Chicago 1947, s. 2. Polskie tłum. cytatu za J. Clifford, O autorytecie etnograficznym..., s. 140. Zbliżoną refleksję odnaleźć można u Carlo Ginzburga, który, jak zauważa James Clifford, proponuje model „wiedzy przypuszczalnej”, a więc zdyscyplinowany, nieuogólniający sposób pojmowania, mający na celu zrozumienie, „w jaki sposób ostrożnie wchodzi się w nieznaną sytuację etnograficzną". J. Clifford, O autorytecie etnograficznym..., s. 141. 
historii jako nauki. Spotkania historii mówionej sprawiły, że zaczęłam bardziej doceniać wagę pozornych niuansów, które często przesądzają o biegu wydarzeń. Dzięki refleksji nad historią mówioną w kontekście „wymiany”, utwierdziłam się w sytuacyjności powstawania wiedzy o przeszłości jako takiej. Ponadto, w mojej opinii, ta metoda badawcza właśnie poprzez swą sytuacyjność pokazuje, że źródła historyczne (nie tylko biograficzne źródła mówione) to często zapis życia konkretnych osób, w związku z tym ich analizy powinny być poparte refleksją, jak dalece można je interpretować $\mathrm{w}$ imię historii ${ }^{31}$. Pogląd ten zyskuje na znaczeniu wówczas, gdy studiom poddaje się opowieści i losy osób, które się zna, z którymi pozostaje się w kontakcie, czego sama doświadczyłam. Oczywiście nie oznacza to, że inne narracje podlegają odmiennym standardom.

Różnego rodzaju relacje z praktyki badawczej pokazują, iż takie doświadczenie historii mówionej nie jest odosobnione. Valerie Yow, autorka podręcznika oral history, w jednym ze swoich artykułów przytacza przykład studentki, przeprowadzającej wywiady z osobami ocalonymi z zagłady. Ich wspomnienia do tego stopnia na nią wpłynęły, iż całkowicie zmieniła swoje poglądy na temat sprawiedliwości i praw człowieka ${ }^{32}$. Marta Duch-Dyngosz, uczestnicząca w projekcie historii mówionej, którego tematem były relacje polsko-żydowskie na Zamojszczyźnie, podsumowując go stwierdza, że dzięki doświadczeniu historii mówionej przekonała się, „że choć mogłoby wydawać się inaczej, ludzie pamiętają i mówią o przeszłości, także tej trudnej i bolesnej, często opowiadają lokalne historie o przechowywanych w czasie wojny Żydach, wskazują domy i nazwiska tych, którzy Żydów zamordowali, bo na przykład skończyły się im pieniądze, i tych, dzięki których pomocy udało się Żydów ocalić. W niektórych wypadkach sprawcy często już nie żyją, ale balast ich czynów przechodzi na kolejne pokolenia. [A także], że antysemici, to również często mili staruszkowie, częstujący

31 O takiej postawie wobec narracji biograficznych pisała Kaja Kaźmierska, zob. np.: K. Kaźmierska, Wywiad narracyjny jako jedna z metod w badaniach biograficznych, „Przegląd Socjologiczny” 2004, t. LIII, z. 1.

32 V. Yow, „Do I Like Them Too Much?”: Effects of the Oral History Interview on the Interviewer and Vice-Versa, „Oral History Review”, 24/1, (Summer) 1997, s. 57-58. Por. Ronald Grele, Envelopes of Sound: The Art of Oral History, Chicago 1975; R.A. Georges, M.O. James, People Studying People. The Human Element in Fieldwork, Berkeley 1980 . 
ciastem i herbatką" ${ }^{\text {33 }}$. Wychodząc poza zakres badań nad zagładą Żydów, również osoby zaangażowane w proces tworzenia Encyklopedii Solidarności, powstającej w ramach współpracy IPN i Pokolenia Stowarzyszenie, podkreślały, że spotkania z tzw. świadkami historii były dla nich cennym doświadczeniem. Zwracały uwagę zarówno na jego aspekt egzystencjalny, jak i epistemologiczny ${ }^{34}$.

Dodatkowo, analiza tekstów opartych na źródłach historii mówionej pozwala zauważyć, że doświadczenie przeprowadzenia wywiadów wpływa także na ich wymiar retoryczny, podobnie jak dzieje się to w rozważaniach z dziedziny antropologii i etnologii. Pisane są one zazwyczaj z perspektywy pierwszej osoby liczby pojedynczej, często wplatane są w nie fragmenty dzienników badawczych, wraz z opisem emocji badacza, które towarzyszyły

33 M. Duch, Historia mówiona - Historie niezapomniane, „Znak”, nr 671, kwiecień 2011, dostęp on-line: http://www.miesiecznik.znak.com.pl/Tekst/pokaz/529/calosc (dostęp: 24. VI 2013 r.).

34 Z wypowiedzi Marcina Dąbrowskiego i Przemysła Miśkiewicza w ramach Seminarium Otwartego z historii Polski XX w.: Prezentacja i dyskusja wokót „Encyklopedii Solidarności", organizowanego przez Katedrę Historii Historiografii i Metodologii Historii oraz Katedrę Dziejów Systemów Totalitarnych Katolickiego Uniwersytetu Lubelskiego Jana Pawła II, 25 III 2013 r., notatki autorki. O doświadczeniu historycznym mówi również Jan T. Gross. W wywiadzie udzielonym tygodnikowi „New Yorker” opowiada o swoim przeżyciu związanym z lekturą opowieści Szmula Wasersztajna oraz z materiałami do dokumentalnego filmu o stosunkach polsko-żydowskich Agnieszki Arnodl. Stwierdza, że w chwili kiedy zobaczył na ekranie kobietę mówiącą: wzięli klucze do stodoty od mojego ojca - co on mógł zrobić?, doznał objawienia, zrozumiał natychmiast wszystko, co się tam stało. Gross w oryginale używa słów I had an epiphany. Jan Gross on Poland's Shame, „New Yorker”, z 6 III 2001 r. Doświadczenie to i przyznanie się do niego, zostało potraktowane jako przyczynek do negatywnej krytyki Sąsiadów. Bogdan Musiał w recenzji tejże publikacji stwierdza, że Gross z góry przesądził wiarygodność słów tzw. świadków historii, nie poddając ich krytyce jako źródła historycznego, jak również iż manipulował źródłami w celu potwierdzenia wcześniej założonej tezy. Zob.: B. Musiał, Tezy dotyczace pogromu w Jedwabnem. Uwagi krytyczne do ksiażki Sasiedzi autorstwa Jana Tomasza Grossa, „Dzieje Najnowsze” 2001, nr 3, s. 252-28o. Przykład ten może służyć również jako przestroga przed przejęciem ze źródła mówionego nie tylko faktów, ale i ich interpretacji. Przestrzegała przed tym Krystyna Kersten i Joseph Goy. Zob.: K. Kersten, Relacje jako typ źródła historycznego, [w:] Pisma rozproszone, wybór i przygotowanie do druku T. Szarota, D. Libionka, Toruń 2005, s. 95; J. Goy, Neosocjologia, „historia oralna”, czyli archiwa oralne historii, „Historyka” 1982, t. XII, s. 69-79. 
konkretnym spotkaniom historii mówionej ${ }^{35}$. Ich autorzy rzadko posługują się strategiami retorycznymi, dzięki którym personalne sądy zostają wyrażone w formie wiedzy obiektywnej. Przeciwnie, poprzez przywołane wcześniej zabiegi, podkreśla się subiektywność opinii i ich zależność od kontekstu.

Doświadczenie historii mówionej posiada dwa pokrewne znaczenia. Może być ono "najbardziej precyzyjnym instrumentem, jakim dysponuje historyk do zrozumienia przeszłości” - jak zauważa Franklin R. Ankersmit - z zastrzeżeniem, że „historia nie jest doświadczeniem fragmentu przeszłości, który najbardziej wpasowuje się we własne wspomnienia historyka, jego wymagania, praktyczne pewniki, jest raczej doświadczaniem fragmentu, który przeciwstawia się intuicjom co do tego, jaki jest świat" ${ }^{\text {"36 }}$. Można je rozumieć także w sensie zapośredniczonym $\mathrm{z}$ antropologii. Jeśli spojrzy się na historię mówioną jako na sytuację „wymiany”, dostrzec można siłę wzajemnych oddziaływań, które mogą sterować każdym z uczestników komunikacji. Micaela Di Leonardo, amerykańska antropolożka, stwierdziła, że najważniejszym wkładem antropologii do historii mówionej jest właśnie zwrócenie uwagi na samoświadomość badaczy, zarówno w wymiarze ich wpływu na budowaną - w ich obecności i przy ich udziale - opowieść o przeszłości, jak i w późniejszym konstruowaniu tekstów ${ }^{37}$. Świadomość postawy badawczej może nie tylko wpływać na sposób prowadzenia badań. Przekazana w narracji - o co postuluje Di Leonardo - może odkrywać przed czytelnikiem uwarunkowania i cel prowadzonych badań. Tym bardziej, wobec faktu, że historia mówiona przez ją praktykujących, często postrzegana jest zarówno jako sposób gromadzenia informacji o wydarzeniach z przeszłości, jak i jako forma moralnego, a czasem również politycznego zaangażowania.

35 Zob. np. P. Filipkowski, Historia mówiona i wojna. Doświadczenie obozu koncentracyjnego w perspektywie narracji biograficznych, Wrocław 2010; W. Kudela-Świątek, op. cit.

36 F.R. Ankersmit, Between Language and History: Rorty's Promised Land, "Common Knowledge”, vol. 6, no. 1, Wiosna 1997, s. 78, polskie tłum. cytatu za: E. Domańska, Mikrohistorie. Spotkanie w międzyświatach, Poznań 2005, s. 106-107.

37 M. Di Leonardo, Oral History as Ethnographic Encounter, "The Oral History Review” 1987, vol. 15, no. 1 (Spring), s. 19, 2 O. 
Agata Stolarz
What makes oral history different from any other history research method is the fact that a historian is actively involved in gathering information about events from the past. A category of performance borrowed from anthropology and ethnology shows that not only may a researcher influence a person narrating their story (e.g. by asking particular questions), it is also the storyteller who may influence the researcher, both in an existential as well as an epistemological dimension. The article discusses the problem of oral history research experience on the basis of an interview that the author carried out with the eighty-three-year old Kazimierz on the topic of the history of Międzyrzec Podlaski. The author presents the influence this interview had on her practicing oral history method as well as the history itself in a wider context.

A reflection on the experience of oral history understood as a kind of research intuition (J. Huizinga) and a form of experiencing a research situation (F. Ankersmit), allows for a closer look at the issue of a researchers' self-awareness and as a result on factors influencing their way of gathering information and the process of constructing history narration. 